\title{
INFLUENCE OF MILLING PROCESS ON MACHINED SURFACE OF POROUS POLYURETHANE (PU) FOAM
}

\author{
Rok Hafner, Franci Pušavec, Luka Čerče, Janez, Kopač
}

Original scientific paper

Nowadays polyurethane modelling foams are successfully replacing original materials in many applications due to certain comparative advantages also in copying artefacts. Milling is a fundamental machining operation frequently used in transforming products of PU foam. This experimental study focuses on surface roughness of milled PU foam. The influences of machining parameters on surface roughness in PU foam milling were assessed. Linear and area surface roughness evaluations after $\mathrm{CNC}$ milling are compared and estimated for the use in future research. Additionally the surface roughness values increase with a feed rate per tooth and decrease with an increase of spindle speed. The milling tests showed significant influence of modelling board density on the final surface roughness. Additional area surface roughness values have been evaluated.

Keywords: milling; polyurethane modelling foam; surface roughness

Utjecaj procesa glodanja na obrađenu površinu porozne poliuretanske (PU) pijene

Izvorni znanstveni članak U ovo doba poliuretanske pjene za modeliranje uspješno zamjenjuju izvorne materijale u mnogim aplikacijama zbog određenih komparativnih prednosti, tako i kod kopiranja artefakta. Glodanje je temeljna strojna operacija koja se često koristi u obradi proizvoda od PU pjene. Ova eksperimentalna studija usredotočuje se na površinsku hrapavost glodane PU pjene. Ocijenjeni su utjecaji parametara obrade na hrapavost površine u procesu glodanja PU pjene. Linearne i površinske procjene hrapavosti nakon CNC glodanja su uspoređene i procijenjene za uporabu u budućim istraživanjima. Isto tako vrijednosti hrapavosti površina povećavaju se s brzinom punjenja po zubu i smanjuju se s povećanjem brzine vretena. Testovi glodanja pokazali su značajan utjecaj gustoće PU pjena za modeliranje na konačnu hrapavost površine. Dodatno su ocijenjene vrijednosti hrapavosti površina.

Ključne riječi: glodanje; poliuretanska pjena za modeliranje; površinska hrapavost

\section{Introduction}

Polyurethane modelling foam is an industrial composite product. The foam structured polyurethane polymers are formed by the reaction of a polyisocyanate with a polyol compound while introducing blowing agent [1]. One of the first applications can be seen in 1940 in a reinforcement of aircrafts. The large-scale usage field of polyurethane (PU) foams is nowadays in majority of thermal appliance insulation and construction because of their very low thermal conductivity. The field of use is expanding to other areas as well. Among them also to the Cultural Heritage field which is of focus in this work. For a while now, the rigid polyurethane foam is in use also for making carriers of copied statues in cultural heritage field, shown in Fig. 1a), b) and c). The mentioned material, with further polychrome layers treatment, seems one of the best replacements for wood and stone as original art materials used in the past. Physical behaviour of material under huge climatic changes over the year in churches and on facades (statues and stucco) defines that material. Thus it can be used in places with extreme fluctuation of atmosphere properties [2]. In order to obtain the best binding conditions of polychrome primer to rigid foam carrier surface, roughness takes an important role.

Machined surface roughness takes an important role since later applied colour layers can have different adhesion to the surface. Final surface properties depend on both: (i) characteristics of ingredients in foaming processes and (ii) milling parameters.

Modelling polyurethane foams have high mechanical and physical properties with respect to their low weight, density values $(\rho)$ ranging between $0,08 \div 1,6 \mathrm{~g} / \mathrm{cm}^{3}$, while compression strengths $(\sigma)$ are between $3,7 \div 100$ $\mathrm{MPa}$. This is due to their cellular structure. Initially this structure was developed through analysis and possibility for substitution of some natural materials such as wood, cork, sponge and coral [3]. Density, strength and thermal expansion are their main characteristics. They are not hard $(30 \div 65$ Shore D) but brittle with lower melting point $\left(150 \div 200{ }^{\circ} \mathrm{C}\right)$ but still they are inflammable. The mechanical and physical properties of polyurethane foams are well documented [4]. Under compression loading, they respond in three phases: a. initial linear elasticity, $b$. plateu as a result of collapse of cell walls and c. densification in the end. Porosity itself, defined with image segmentation technique [5], plays a huge role, but it is believed that surface roughness can be partially controlled with milling parameters. Final surface properties can be then considered as a set of two influences: 1. Surface roughness as a result of milling parameters and 2. The primary surface roughness as a property of milled material with its density and the components (type of filler) of which the foam is made [6].

An ideal surface roughness of statues carriers, measured on the basis of empirical aspects is around 16 $\mu \mathrm{m}$ of average roughness $(R a)$. With increased density of the foam, porosity decreases. This positively affects the primary surface roughness and strength of the object. However, strength to weight ratio is one of the key characteristics of the so-branched shapes as statues are. Higher densities provide higher values of both strength and weight. On the other side, prices of material rise proportional to their density. From empirical point of view, in use are rigid polyurethane foams of densities between 0,25 to $0,45 \mathrm{~g} / \mathrm{cm}^{3}$. Those are middle class cellular materials, specified as densities between 0,2 to $0,5 \mathrm{~g} / \mathrm{cm}^{3}$ [4]. Polyurethane foams of those densities are relatively easy to maneuver, while still keeping necessary characteristics. Statues of larger dimensions are often 
located in hard to reach areas and at higher altitudes. For such cases middle class density rigid foams still provide a sufficient stability with respect to the weight.

Machining in general presents no difficulties, because cutting forces are low [7] and increase with PU foam density. However, the response of their brittle cellular structure to the machining conditions is still questionable, especially when considering machined surface roughness.

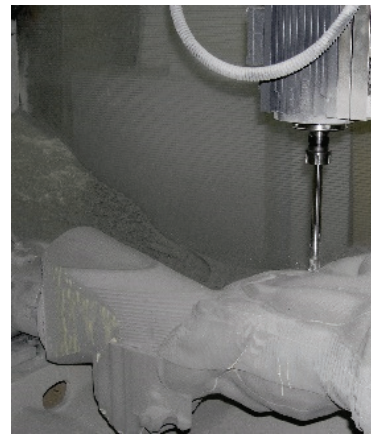

a)

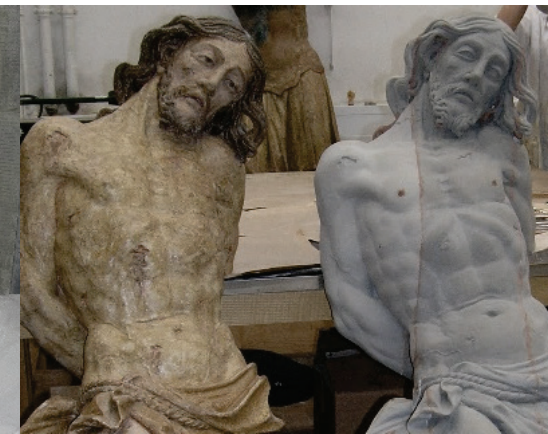

b)

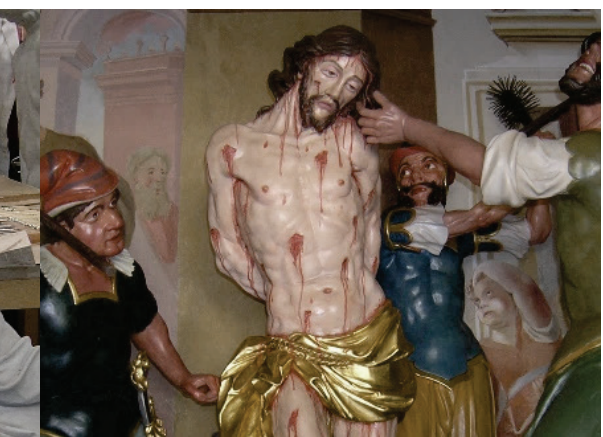

c)

Figure 1 a) CNC milling process, b) Original and copy's carrier, c) Finished copy

\section{Material and methods}

There were performed two experiments. With the first experiment the levels of influence of individual milling parameters were determined. In the second experiment there was only feed per tooth varying as the most influenced factor. It was shown that the same surface roughness values are possible to be achieved between different foam densities also.

Face milling experiments were carried out on SODICK MC 430L high precision CNC milling machine with $40000 \mathrm{rpm}$ of maximum spindle speed. "One stroke in one direction" milling strategy was used. Milling process was carried out at consistent room temperature of $21{ }^{\circ} \mathrm{C}$. The $6 \mathrm{~mm}$ diameter two bladed router cutter WIDIN ZEMUS end mill tx302060 (Fig. 2) was used instead to avoid possible effects of tool swinging on micro level with square end and helix of $30^{\circ}$.

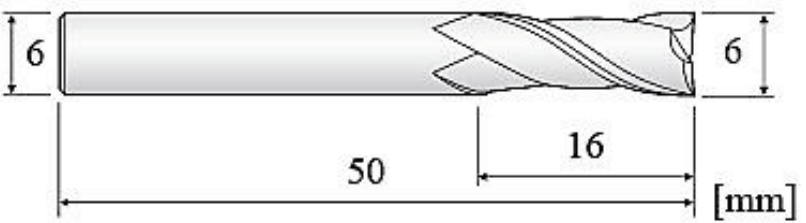

Figure 2 WIDIN ZEMUS end mill tx302060 characteristics

Table 1 Experimental cutting conditions for evaluation factor's significance

\begin{tabular}{|c|c|c|c|c|}
\hline Std & $\begin{array}{c}\text { Foam density } \\
\left(\mathrm{g} / \mathrm{cm}^{3}\right)\end{array}$ & $\begin{array}{c}\text { Feed per tooth } \\
(\mathrm{mm})\end{array}$ & $\begin{array}{c}\text { Spindle speed } \\
(\mathrm{rpm})\end{array}$ & $\begin{array}{c}\text { Axial cut depth } \\
(\mathrm{mm})\end{array}$ \\
\hline 1 & 0,7 & 0,02 & 10,000 & 0,05 \\
\hline 2 & 0,7 & 0,10 & 20,000 & 0,50 \\
\hline 3 & 0,7 & 0,18 & 30,000 & 0,95 \\
\hline 4 & 1,2 & 0,02 & 20,000 & 0,95 \\
\hline 5 & 1,2 & 0,10 & 30,000 & 0,05 \\
\hline 6 & 1,2 & 0,18 & 10,000 & 0,50 \\
\hline 7 & 0,7 & 0,02 & 30,000 & 0,50 \\
\hline 8 & 0,7 & 0,10 & 10,000 & 0,95 \\
\hline 9 & 0,7 & 0,18 & 20,000 & 0,05 \\
\hline
\end{tabular}

For evaluation of factor's significance in the first experiment two extreme values of densities of polyurethane foams were used, Necuron 1020 and Necuron 651 from Necumer. The basic characteristics of those foams are shown in Tab. 2. Experiments were aimed to evaluate most significant factor defining surface quality. Moulded larger PU modelling boards were sawn in to smaller test samples of dimensions $50 \times 30 \times 25$ $\mathrm{mm})$.

Analysis of variance table study was prepared based on average values of surface roughness, obtained from experiments.

Analysis of the first experiment with its procedure enabled determination of milling parameters of great effect on surface roughness. Tab. 1 shows the machining parameters used in performing milling tests.

In second experiment feed per tooth was varying randomly between values 0,005 and $0,3 \mathrm{~mm}$. Feed per tooth is, determined from the first experiment, one of the basic influences to surface quality in milling processes right after the spindle speed. The spindle speed has been fixed to the highest possible $40000 \mathrm{rpm}$ providing maximum productivity. This preliminary study provided information, required to assess the size of impact on surface quality.

Polyurethane modelling foams with most common used densities in cultural heritage field were used, Renshape BM 5185 and BM 5025 from Huntsman. The basic characteristics of those foams are shown in Tab. 2 . Most of the physical characteristics of polymer foams are directly connected with their density [4], determined according to ISO 1183. Test samples were also sawn out of larger boards into the same dimensions.

Table 2 Properties of tested PUR modelling boards.

\begin{tabular}{|l|c|c|c|c|}
\hline $\begin{array}{c}\text { Modeling board } \\
\text { reference }\end{array}$ & $\begin{array}{c}\text { Foam } \\
\text { density } \\
\left(\mathrm{g} / \mathrm{cm}^{3}\right)\end{array}$ & $\begin{array}{c}\text { Flexural } \\
\text { strength } \\
(\mathrm{MPa})\end{array}$ & $\begin{array}{c}\text { Compressive } \\
\text { strength } \\
(\mathrm{MPa})\end{array}$ & $\begin{array}{c}\text { Hardness } \\
(\text { Shore D) }\end{array}$ \\
\hline Necuron 301 & 0,30 & 6 & 5 & approx. 37 \\
\hline Necuron1020 & 1,20 & 79 & 82 & approx. 80 \\
\hline Renshape BM 5025 & 0,25 & 5,5 & 3,7 & - \\
\hline Renshape BM 5185 & 0,45 & $10-15$ & $10-15$ & - \\
\hline \multicolumn{5}{|c}{ * Unavailable data. }
\end{tabular}

\subsection{Surface characteristics measurement}

Surface evaluation was performed with standard technique, measuring with 2D profilometer MitutoyoSurftest SJ - 301, providing surface roughness measurement of one profile. An average value of three 
measurements was taken. In addition, area surface roughness $(3 \mathrm{D})$ was performed in second analysis with 3D scanning device, developed for characterizing the surface topography [8]. Measuring system is a combination of a high - accuracy 2D laser displacement sensor Keyence LJ G015 with proper controller [9] and linear motorized translation stage Standa 8MT173 DCE2 shown in Fig. 3. Data in 3D point cloud provided via LabVIEW application form were evaluated using GOM Inspect software.

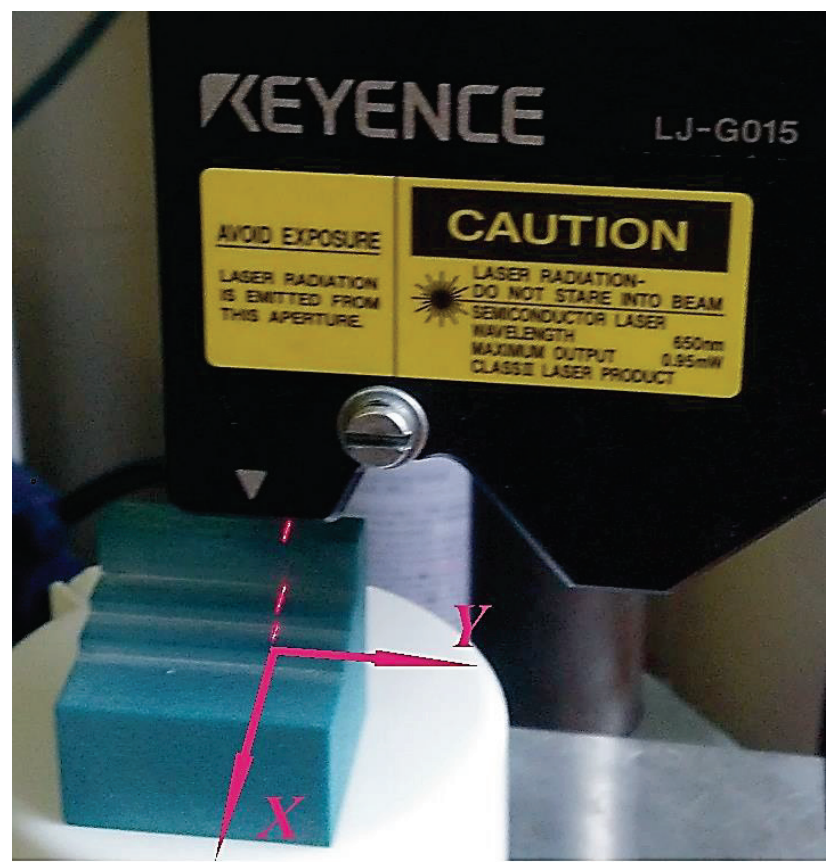

Figure 3 Laser displacement sensor, mounted on translation stage

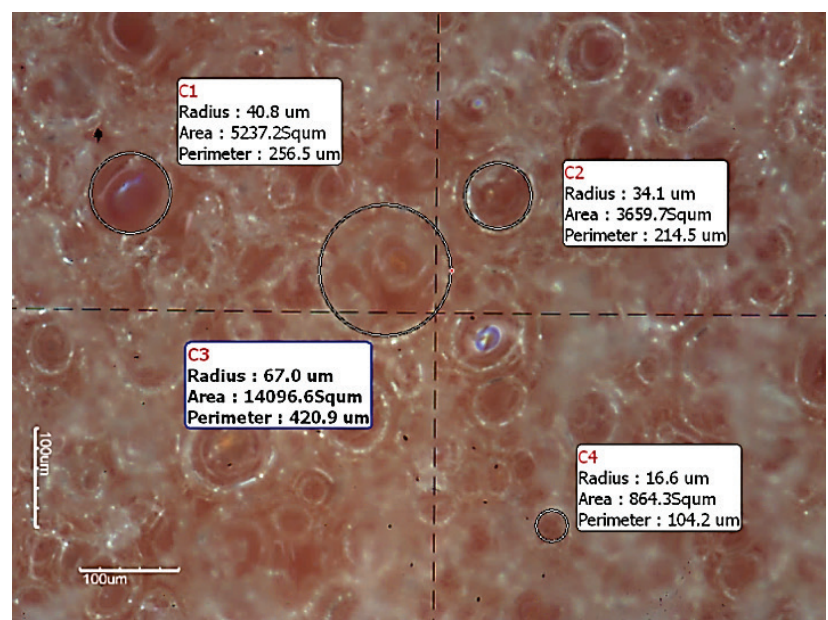

Figure 4 Mitutoyo TM microscope analysis of pore sizes of Renshape BM 5185 modelling board

Sensor gathered surface information from highlighted surface of specimen with translated linear laser beam. The measurement range of this system is $7 \mathrm{~mm}$ in $X$-axis and 5 $\mathrm{mm}$ in $Y$-axis. In the longitudinal direction of laser beam ( $X$-axis) the accuracy depends on the CMOS sensor density and it is permanent $10 \mu \mathrm{m}$ with repeatability of 2,5 $\mu \mathrm{m}$. In the direction of motorized linear translation stage ( $Y$-axis) minimum incremental motion is $0,1 \mu \mathrm{m}$ and can be preset. Higher step motions of translation stage provide capture of larger areas. Basic topographical characteristics of used modelling boards allow preset to step of $5 \mu \mathrm{m}$. An average value for each surface was calculated on the basis of four taken measurements.

Measurement accuracy of laser scanning system, powered by KEYENCE provides a high - definition data for the surface of foams with pore sizes not smaller than $15 \mu \mathrm{m}$. This perimeter represents three times the value of preset step of $5 \mu \mathrm{m}$ in $Y$-axis. PU foams, used for making copies in cultural heritage field are specified as middle class cellular materials with measured average pore sizes around $40 \div 60 \mu \mathrm{m}$. Average pore size's values of foams with specific density were obtained from several measurements of pore's diameter in Mitutoyo TM microscope (Fig. 4). Keyence measurement system is thus appropriate to get accurate measured values.

\subsection{Surface measurement analysis}

Laser scanned surface areas as 3D point clouds were treated with 3D point cloud evaluation software. After cleaning off noise picture look like uneven, with bumpy surface. On that surface the virtually regular plane was projected in the best fit position between all the points in cloud as a zero base. Standard deviation $(S D)$ for all the points in cloud was calculated with respect to zero base plane by the software.

\section{Results and discussion}

The results of the experiments allowed the evaluation of the surface roughness of PU foams as a function of cutting parameters. Average surface roughness values, obtained from experiments were used in ANOVA tables (Tab. 3) of the first analysis. The influence of cutting parameters on surface roughness has been determined. In Tab. 3 are presented $p$-values, which are indicators of significance. $p$-values, smaller than 0,05 indicate strong significance. The Model $F$-value of 9,53 implies that the model is significant. It is evident that modelling board density has the most significant influence on surface quality from either presented factors (machining parameters). Spindle speed is still significant but not enough.

Table 3 The table of variance analysis

\begin{tabular}{|l|c|c|c|c|c|}
\hline \multicolumn{1}{|c|}{ Source } & $\begin{array}{c}\text { Sum of } \\
\text { squares }\end{array}$ & $d f$ & $\begin{array}{c}\text { Mean } \\
\text { square }\end{array}$ & $F$-value & $p$-value \\
\hline Model & 29,81 & 4 & 7,45 & 9,53 & 0,0254 \\
\hline Modelling board & 24,64 & 1 & 24,64 & 31,50 & 0,0050 \\
\hline Feed rate & 0,72 & 1 & 0,72 & 0,92 & 0,3914 \\
\hline Spindle speed & 3,90 & 1 & 3,90 & 4,99 & 0,0892 \\
\hline Axial cut depth & 0,55 & 1 & 0,55 & 0,70 & 0,4505 \\
\hline
\end{tabular}

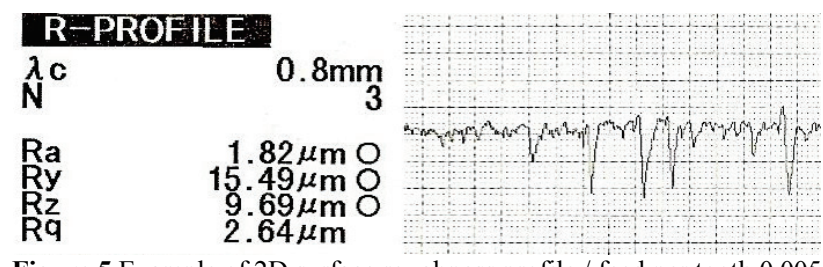

Figure 5 Example of 2D surface roughness profile / feed per tooth 0,005 $\mathrm{mm}$, foam density $1,2 \mathrm{~g} / \mathrm{cm}^{3}, R a=1,82 \mu \mathrm{m}$

Fig. 5 and 6 present 2D surface roughness profiles obtained with two extreme cutting parameters situations (small feed per tooth and high foam density vs. high feed per tooth and small foam density). It is evident that foam 
density and feed per tooth have a strong influence to the surface roughness.

\section{REPROFIIE}

$\hat{N}^{\mathrm{C}}$ $2.5 \mathrm{~mm}$

$\mathrm{Ra} \star 28.94 \mu \mathrm{m} \mathrm{O}$ Ry $\mathrm{Rq} \quad \$ 35.43 \mu \mathrm{m}$

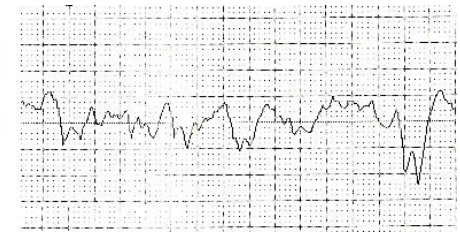

Figure 6 Example of 2D surface roughness profile / feed per tooth 0,3 $\mathrm{mm}$, foam density $\rho=0,25 \mathrm{~g} / \mathrm{cm}^{3}, R a=28,94 \mu \mathrm{m}$

According to measured surface roughness values of second analysis it is evident that machining parameters have strong influence on surface quality, despite the great significance of the PU foam density. With lower significant machining parameter (feed per tooth), it is already possible to achieve great differences in surface roughness value of middle class cellular materials. Since $16 \mu \mathrm{m}$ of $R a$ it is the best surface roughness from empirical aspect of view. Tab. 4 shows that it is possible to reach the desired value with different density of PU modelling foam. It was shown that even the factor with minor effect can assure the same surface roughness value on two rigid foams with different densities.

Table 4 Measured surface roughness values.

\begin{tabular}{|c|c|c|c|c|c|c|c|c|}
\hline \multirow{2}{*}{ Modelling board } & \multirow{2}{*}{ Measurement method, $\mu \mathrm{m}$} & 0,005 & 0,02 & 0,05 & 0,075 & 0,1 & 0,2 & 0,3 \\
\cline { 3 - 9 } & & 27,61 & 41,15 & 50,42 & 59,26 & 59,87 & 62,67 & 62,92 \\
\hline \multirow{2}{*}{ Renshape BM 5025 } & $S D$ & 15,48 & 18,66 & 19,60 & 20,13 & 21,73 & 23,09 & 26,10 \\
\hline \multirow{2}{*}{ Renshape BM 5185 } & $R \mathrm{a}$ & 21,09 & 26,65 & 31,18 & 33,40 & 35,07 & 37,11 & 37,36 \\
\cline { 2 - 9 } & $\mathrm{SD}$ & 12,03 & 18,66 & 19,60 & 20,13 & 21,73 & 23,09 & 26,10 \\
\hline
\end{tabular}

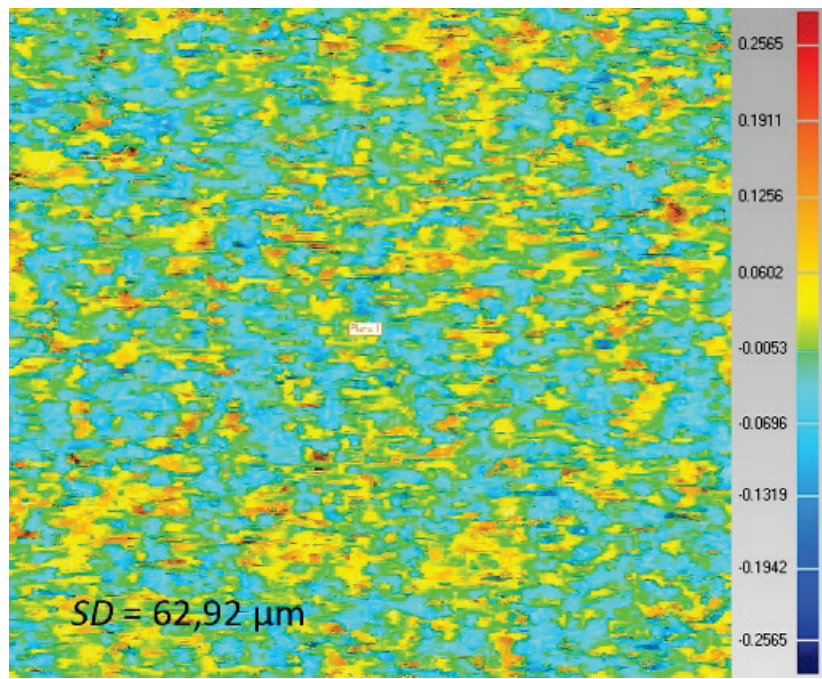

Figure 7 PU foam of density $\rho=0,25 \mathrm{~g} / \mathrm{cm}^{3}$, machined with $f_{\mathrm{z}}=0,3 \mathrm{~mm}$ of feed per tooth

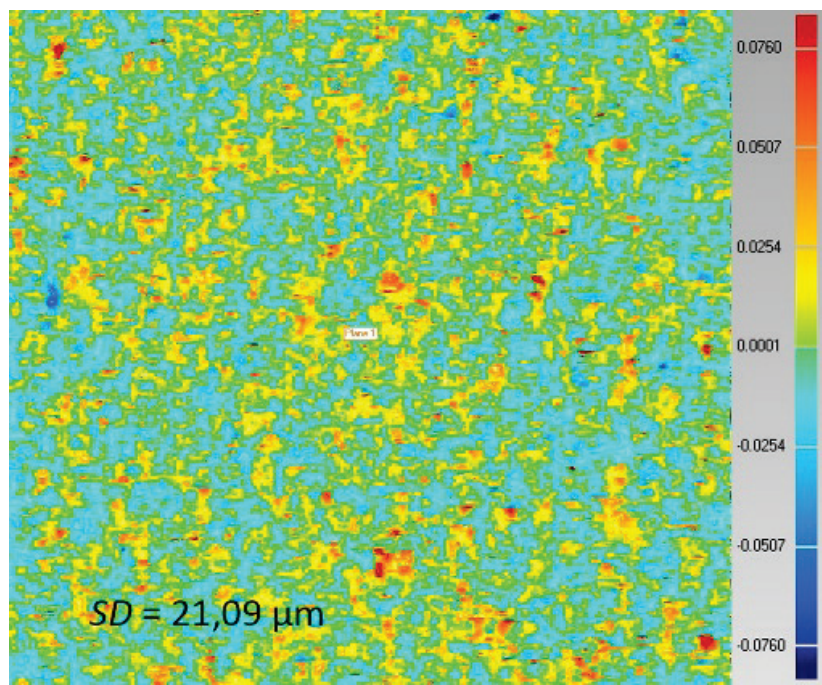

Figure 8 PU foam of density $\rho=1,2 \mathrm{~g} / \mathrm{cm}^{3}$, machined with $f_{\mathrm{z}}=0,005$ $\mathrm{mm}$ of feed per tooth

Overall 3D profile roughness characteristics of the two extreme parameters samples (high feed per tooth and small foam density vs. small feed per tooth and high foam density), shown in Fig. 7 and 8, are distinguished by nonuniform contours and distributions of anatomical elements (foam density $\rho=0,25 \mathrm{~g} / \mathrm{cm}^{3}$ ) or finer peaks to valleys structure (foam density $\rho=1,2 \mathrm{~g} / \mathrm{cm}^{3}$ ). The colour on plots corresponds to surface roughness. Areas between light blue and light green colour present an arithmetic mean, while colours toward dark blue show the valleys and colours toward dark red the peaks.

The surface accuracy was evaluated by standard deviations $(S D)$ of $3 \mathrm{D}$ point cloud, gathered with $3 \mathrm{D}$ scanning device, from an ideal flat surface, positioned in an arithmetic mean.

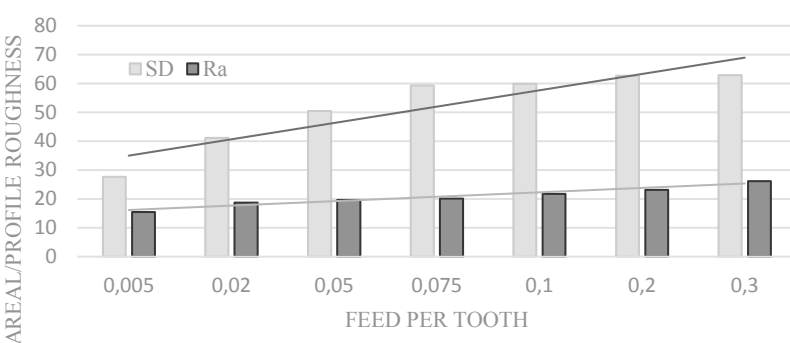

Figure 9 Roughness of area and profile roughness of BM 5025

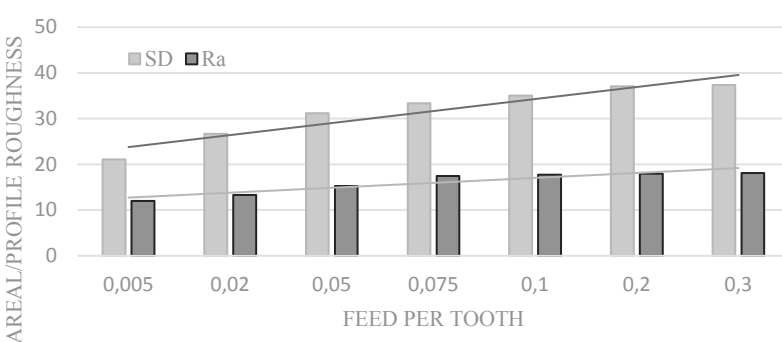

Figure 10 Roughness of area and profile roughness of BM 5185

Differences between surface area (3D) and linear (2D) roughness values in Fig. 9 and 10 for different foam densities are well distinguished. Surface roughness values increase proportionately with feed per tooth. Area roughness values are in all cases greater than surface roughness values of profiles [10]. There is also a certain 
relationship between $R a$ and $S D$ for an average coefficient 0,45 . Laser measurement system with spacing $5 \mu \mathrm{m}$ in 5 $\mathrm{mm}$ long translation allows 1000 profiles in just one measurement. Such amount of profiles contains numerous high peaks and deep valleys. With 2D profilometer there were only three profiles measured on the basis of which an average value was calculated. This is a source for higher area surface roughness value measuring.

\section{Conclusion}

Polyurethane foams are used for many common and industrial applications, especially in automotive industry. Milling is a most common machining operation encountered. Among all applications in industry this material and machining process reached cultural heritage field also, where surface roughness plays an important role. Therefore, in this study the effects of milling process parameters such as feed per tooth $\left(f_{\mathrm{z}}\right)$, cutting speed $\left(v_{\mathrm{c}}\right)$ and vertical step $\left(a_{\mathrm{p}}\right)$ in face $\mathrm{CNC}$ milling process was tried determining on surface roughness quality with different PU foam densities.

The results showed that foam density significantly affects the surface roughness quality. However, milling parameters still have evident influence. The work shows that it is possible to achieve the desired surface quality of rigid polyurethane foams with different densities, varying even less significant machining factor. Understanding the impact of cutting parameters allows a wider range of material flexibility and consequently cost reduction. A theoretical evaluation of empirical ideal surface quality has been a matter of this research, where the adhesion of primer layers will be tested in the future work.

\section{Acknowledgements}

The authors would like to acknowledge the cooperation between LABOD - Laboratory of machining, Faculty of Mechanical Engineering, University of Ljubljana (labod.fs.uni-lj.si), Department of Thin Films and Surfaces, Institut Jozef Stefan (ijs.si/ijsw/F3) and Department of Materials Science and Metallurgy, Faculty of Natural Sciences and Engineering, University of Ljubljana (omm.ntf.uni-lj.si).

\section{References}

[1] Allen, N. S.; Edge, M.; Horie, C. V. Polymers in Conservation. Royal Society of Chemistry, Michigan, 1992.

[2] La Pense, A.; Parsons, J.; Cooper, M. The Use of Laser Scanning and 3D Modelling in the Realisation of an Artistic Vision - Productinon of Large Scale Public Art in Tudorsquare, Shefield. // International archives of photogrammetry, XXXVI, 5, Commision V Symposium / Newcastle upon Tyne, 2010.

[3] Gibson, L. J.; Ashby, M. F. Cellular Solids - Structure \& Properties. Cambridge University Press. $2^{\text {nd }}$ ed. Cambridge, 1997. DOI: $10.1017 /$ CBO9781139878326

[4] Klempner, V.; Sendijarevic, D. Handbook of Polymeric Foams and Foam Technology. 2nd ed. Carl Hanser Verlag, Munich, 2004.

[5] Malcolm, A. A.; Leong, H. Y.; Sponwage, A. C.; Shacklock, A. P. Image segmentation and analisys for porosity measurement. // Journal of materials Processing technology. 192-193(2012), pp. 391-396. DOl: 10.1016/j.jmatprotec.2007.04.041

[6] Patel, K.P. Experimental Analysis On Surface Roughness of CNC End Milling Process using Taguchi Design Method. // Journal of Materials Processing Technology. 4, 2(2012), pp. 391-396.

[7] Malak, S. F. F.; Anderson, I. A. Orthogonal Cutting of Polyurethane Foam. // International Journal of Mechanical Sciences. 47, 6(2005), pp. 867-883. DOI: 10.1016/j.jimecsci.2005.02.002

[8] Cerce, L.; F. Pusavec; J. Kopac. A New Approach to Spatial Tool Wear Analysis and Monitoring. // Journal of Mechanical Engineering. 61, 9(2015), pp. 489-497. DOl: 10.5545/sv-jme.2015.2512

[9] Keyence, High - accuracy 2D displacement sensor, Keyence, Editor. 2010.

[10] Manas, K.; Swoboda, E.; Dvorakova R. Measuring of Surface Structure and their Analisys. // Trends in the Development of Machinery and Associated Technology, 13th International Research-Expert Conference / Hammamet, Tunisia, 2009.

\section{Authors' addresses}

Rok Hafner, acad. rest. Faculty for Mechanical Engineering Aškerčeva 6,1000 Ljubljana, Slovenia rok.hafner@gnom.si

Franci Pušavec, assist. prof. dr. Faculty for Mechanical Engineering Aškerčeva 6, 1000 Ljubljana, Slovenia franci.pusavec@fs.uni-lj.si

Luka Cerce, bsc. mech. eng. Faculty for Mechanical Engineering Aškerčeva 6, 1000 Ljubljana, Slovenia luka.cerce@fs.uni-lj.si

Janez Kopač, prof. dr. Faculty for Mechanical Engineering Aškerčeva 6, 1000 Ljubljana, Slovenia janez.kopac@fs.uni-lj.si 